\title{
Yuba River analysis aims to aid spring-run chinook salmon habitat rehabilitation
}

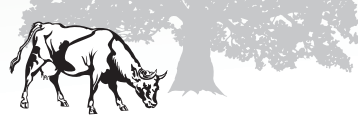

\author{
by Gregory Pasternack, Aaron A. Fulton and \\ Scott L. Morford
}

\section{Spring-run chinook salmon his-} torically migrated far upstream into Sierra Nevada rivers but are now confined to gravel-limited reaches below large dams ringing the Central Valley. In this study, topographic analysis and photo interpretation reveal the 100-year history of channel conditions in the bedrock canyon on the Yuba River below Englebright Dam, which also abuts the UC Sierra Foothill Research and Extension Center. Historical evidence shows that alluvial bars provided spring-run chinook salmon habitat in the reach prior to gold mining and that the influx of hydraulic mining debris dramatically expanded it. However, when Englebright Dam was completed in 1941 , shot rock was left in the canyon and allowed to migrate downstream, where it buried gravel bars. We recommend that shot rock be removed to exhume a pre-existing large gravel bar and that new river gravels be placed in the canyon to create salmon habitat.

$\mathrm{M}$ ost large tributaries to the Sacramento and San Joaquin rivers, which drain the Sierra Nevada, have large dams. Immediately downstream of several of these structures there are continuous stretches (greater than 0.31 miles [0.5 kilometers]) of exposed (or covered by a transient sediment veneer) bedrock channel (Wohl and Tinkler 1998). These stretches occur on the Sacramento River as well as the Feather, Yuba, Calaveras and Stanislaus rivers. In some cases a bedrock canyon may always have existed (e.g., Yuba), while in others, channel and floodplain sediments were scoured away by long-

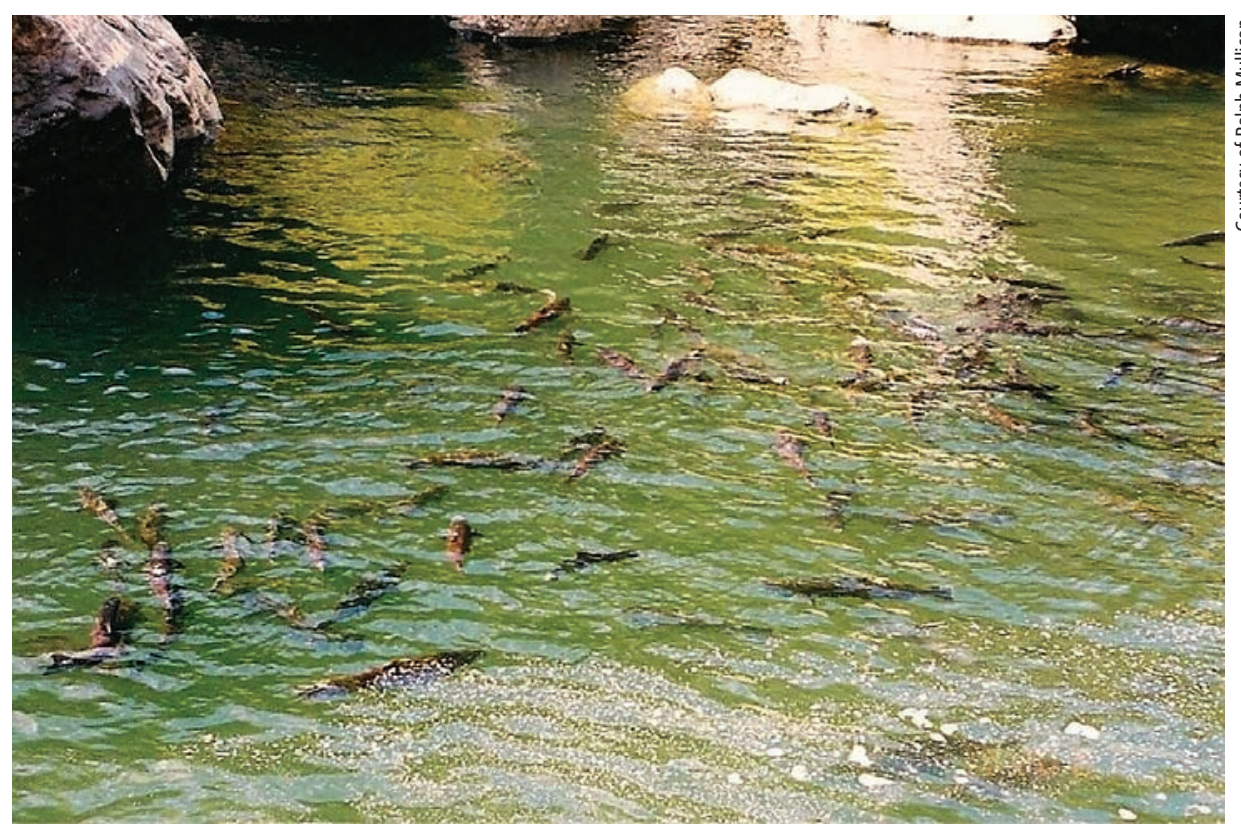

Adult spring-run chinook salmon hold in the Englebright Dam Reach of the lower Yuba River.

duration low flows that focused on riffles (a river's higher elevation areas; pools are lower elevation) and infrequent floods that affected other channel land forms after the dam cut off the resupply of sediment (e.g., Feather).

Four distinct races of anadromous chinook salmon occupy the Sacramento/San Joaquin river system (Banks et al. 2000), but for spawning they all prefer common physical attributes of a river: cool temperature, gravel and cobble bed material, low depth (about 0.5 to 4 feet) and moderate velocity (2 to 4 feet per second). The spring-run chinook salmon is a federally threatened species that is differentiated by the time at which adults migrate from the ocean to fresh water systems (Yoshiyama et al. 1996). Spring-run chinook salmon generally enter fresh water between April and June and oversummer in cool, highelevation pools before spawning on main-stem gravel riffles in August and September. Before dams blocked their migration, this life-history strategy enabled spring-run chinook salmon to migrate to gravel riffles high up in Sierra Nevada watersheds during snowmelt events, because high flows inundate natural cascades enough to allow fish to swim over them. Later runs of chinook salmon encounter the same features at low flows, when the channels form nearly dry, impassable cliffs (Yoshiyama et al. 1996). The dramatic decline in spring-run chinook salmon in California has been attributed to dams, which block up to $80 \%$ of their historic habitat (Wheaton et al. 2004a).

Under a regulated flow regime, spring-run chinook salmon migrate to the bedrock reaches at the base of large water-supply dams in the spring and summer and hold in pools supplied with cold water releases from the bottom of reservoirs. In the early fall they attempt to spawn, but the absence of gravel to hold and protect embryos causes spawning to fail. On Butte Creek, a small stream with warm water at the time spring-run chinook salmon oversummer, a large minority (38\%) were reported in 2007 to abandon upward migration and head back downstream to spawn in suitable gravel-bed habitat (McReynolds and Garman 2008). However, while there is more spawning habitat downstream, the warmer temperatures are unfavorable. The majority of salmon attempt to spawn because 


\section{Glossary}

Alluvial (alluvial fill): Loose, unconsolidated sediment moved by water.

Backwater: Shallow, very slow (or stagnant) flow adjacent to the main flow and separated from it by a peninsula.

Bars (gravel, alluvial, shot rock):

Deposits of alluvial sediment.

Base flow: Low water discharge in a river fed by groundwater during dry periods.

Chute: Fast, steep and moderately deep flow.

Emergent alluvial point bars: Point bar that is not underwater.

Forced pool: Deep-water area adjacent to a bedrock outcrop.

Geomorphic: Changes to the surface of the Earth.

Glide: Shallow, slow flow.

Hyporheic: Water moving through sediment below the riverbed.

Point bar: Sedimentary deposit on the inside of a meander bed in a river.

Pool: Deep-water area surrounded by alluvial sediment.

Reach (gravel-limited reach): Section of a river defined by its geomorphic attributes such as slope, degree of bedrock exposure, bed material size, width, width-to-depth ratio and degree of channel entrenchment.

Recirculation: Upstream-directed flow usually behind a flow obstruction.

Riffle (main-stem gravel riffle): Flow

that is shallow and fast as it goes downhill.

Riffle entrance: Transitional area between an upstream pool and a downstream riffle.

Riverbed: Bottom boundary between liquid and solid media in a channel.

River slope: Change in elevation per unit length down a channel.

Run: Moderately fast, moderately steep, and moderately deep flow.

Secondary channel: A smaller channel that flows perennially and is connected at both ends to the main channel.

Substrate size classes (boulder, cobble/gravel, sand/mud): Sand is 64 microns to 2 millimeters; gravel is 2 to 64 millimeters; cobbles are 64 to 256 millimeters; boulders are more than 256 millimeters.

Wall slope: Change in elevation per unit length down a hillside toward a river.

Source: Pasternak 2008 cold water is more amenable for holding adults. In perennial cold-water streams like the Feather and Yuba, downstream migration may be even less likely. For example, in 2007 the authors observed spring-run chinook salmon attempting to spawn on bedrock covered with a thin veneer of angular gravel on the Yuba River below Englebright Dam. Overall, bedrock reaches at the base of large dams can play a key role in spring-run chinook salmon viability.

An assessment of the bedrock reach below Englebright Dam on the Yuba River has been ongoing (Fulton 2008; Pasternack 2008). Detailed hydrodynamic, sedimentary and biological assessments of current conditions have been made. However, current conditions often reflect both natural history and human impacts, which are difficult to explicitly incorporate into predictive models, although they do constrain future outcomes. Our study focuses on channel changes in a key spring-run chinook salmon spawning zone below Englebright Dam on the Yuba River (fig. 1). We document human impacts arising from gold and gravel mining, and the building of the Englebright Dam in 1941. The study area includes the tributary junction with Deer Creek. The north bank of the Yuba River at this location, including the Sinoro Bar, is owned by UC and operated as part of the UC Sierra Foothill Research and Extension Center. This facility provided logistic support for our research. Together with other property owners, they also provided essential access to the site. Based on our analysis of the study area, we offer specific management recommendations.

\section{Englebright Dam Reach}

The 1,350-square-mile (3,490-squarekilometer) Yuba River basin (fig. 1, inset) has hot, dry summers and cool, wet winters. Relative to other Sierra basins, its mean annual precipitation is among the highest (greater than 59 inches [1,500 millimeters]), so its development for hydropower, water supply, flood regulation, gold mining and sediment control (James 2005) is not surprising. During the Gold Rush (mid- to late 19th century), hillsides were hydraulically mined until the practice was outlawed in 1884. In the absence of dams, vast

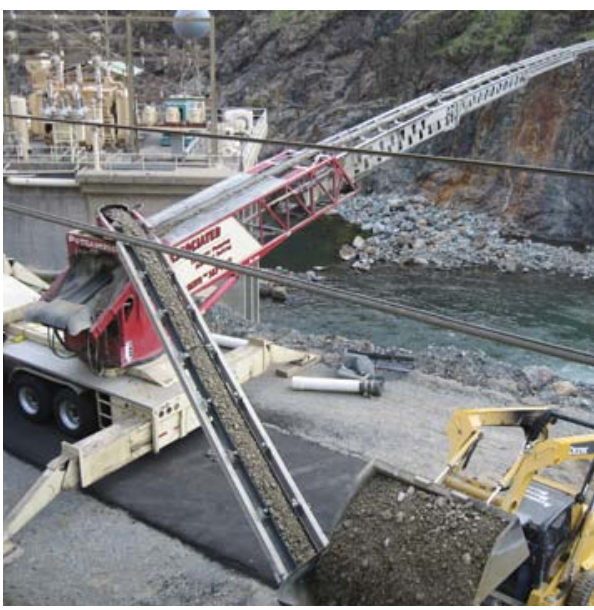

In 2007, the U.S. Army Corps of Engineers injected about 450 metric tons of gravel and cobble below the Englebright Dam in order to mitigate impacts to spring-run chinook salmon, which need gravel to spawn.

hillside-mining sediments - about 684 million cubic yards (522 million cubic meters) - moved freely down the river network filling in valleys, smothering aquatic habitat and deterring salmon from entering the system (Curtis et al. 2005). At the time, salmonid populations had plenty of alternative rivers in California to use to survive this localized disturbance. Today, flow regulation, bank alteration, channelization and in-channel gold and gravel mining also affect the rivers.

These forces starve rivers of sediment. Englebright Dam (capacity of just 108 million cubic yards [82.6 million square meters]) was built as a sediment barrier on the mainstem, downstream of the confluences with major tributaries, to stop sediment from further filling in rivers on the floor of the Central Valley and causing costly flooding and damage to agriculture there. In 1971, 30 years later, the New Bullards Bar Reservoir (capacity of 1.56 billion cubic yards [1.19 billion cubic meters]) was built on the North Yuba for water supply and flood control. The Englebright and New Bullards Bar dams restrict salmon access to $73 \%$ of historic habitat areas. A remnant population of less than 1,000 spring-run chinook salmon persists below Englebright Dam compared to a combined average remnant population of 14,000 fall and late-fall chinook salmon. There are no estimates for pristine, historic salmonid populations on the Yuba, but Yoshiyama et al. (1996) reported qualitative historic information suggesting that they were much larger. Were it not for the presence of the historic gold-mining debris, sal- 
The impact of mechanized instream mining was significantly greater than the impact of Englebright Dam on changing the geometry and structure of Sinoro Bar.

monid habitat conditions today would be dramatically worse than they are, as is evident for other rivers in the region.

Stream flow is recorded at the U.S. Geological Survey's Smartville gage (\#11418000), 0.3 mile (0.5 kilometer) downstream of Englebright Dam. Between 1942 and 1971, the statistical bankful discharge $\left(\mathrm{Q}_{\mathrm{b}}\right.$, defined as the flow that fills the geometric shape of a channel and approximated by the event with a 1.5-year probabilistic recurrence interval) at Smartville gage was 11,600 cubic feet per second (328.5 cubic meters per second). In the period since 1971, the gage's $Q_{b}$ has been 5,620 cubic feet per second (159.2 cubic meters per second). Given that the Middle and South Yuba tributaries lack large reservoirs, winter storms and spring snowmelt produce floods that overflow the top of Englebright Dam and flow into Englebright Reach.

The lower Yuba River is about 24 miles (38 kilometers) long from Englebright Dam to its junction with the Feather River. Steelhead trout and chinook salmon utilize the lower Yuba River for spawning, rearing and migration. The habits and life-cycle patterns of spring-run chinook salmon are poorly documented on the lower Yuba River, which is managed by diverse local, state and federal entities.

The Englebright Dam Reach extends from Englebright Dam down to the junction with Deer Creek (fig. 1). It is a relatively straight bedrock canyon with a veneer of "shot rock" debris. Shot rock is irregular-shaped angular cobbles and boulders blasted from surrounding hillsides. In this reach, shot rock was generated and spread by two distinct processes: rock excavation during the construction of Englebright Dam and hillside scouring during major floods. Englebright Dam Reach is also influenced by a backwater effect imposed by Deer Creek, since flood pulses out of Deer Creek usually come ahead of the larger and more snowmelt-driven inflows from the Yuba River.
There are three shot-rock deposits in the Englebright Dam Reach (fig. 1). The largest is a mixture of angular cobbles and boulders deposited as a point bar upstream of the junction with Deer Creek on the north bank. This point bar has recently been named Sinoro Bar to symbolize the lack of gold expected in it.

On Nov. 29, 2007, the U.S. Army Corps of Engineers put about 450 metric tons (360 cubic yards) of rounded gravel and cobble into the river below Englebright Dam. That experiment aims to ascertain the likely fate of larger amounts of gravel to be added into the river in

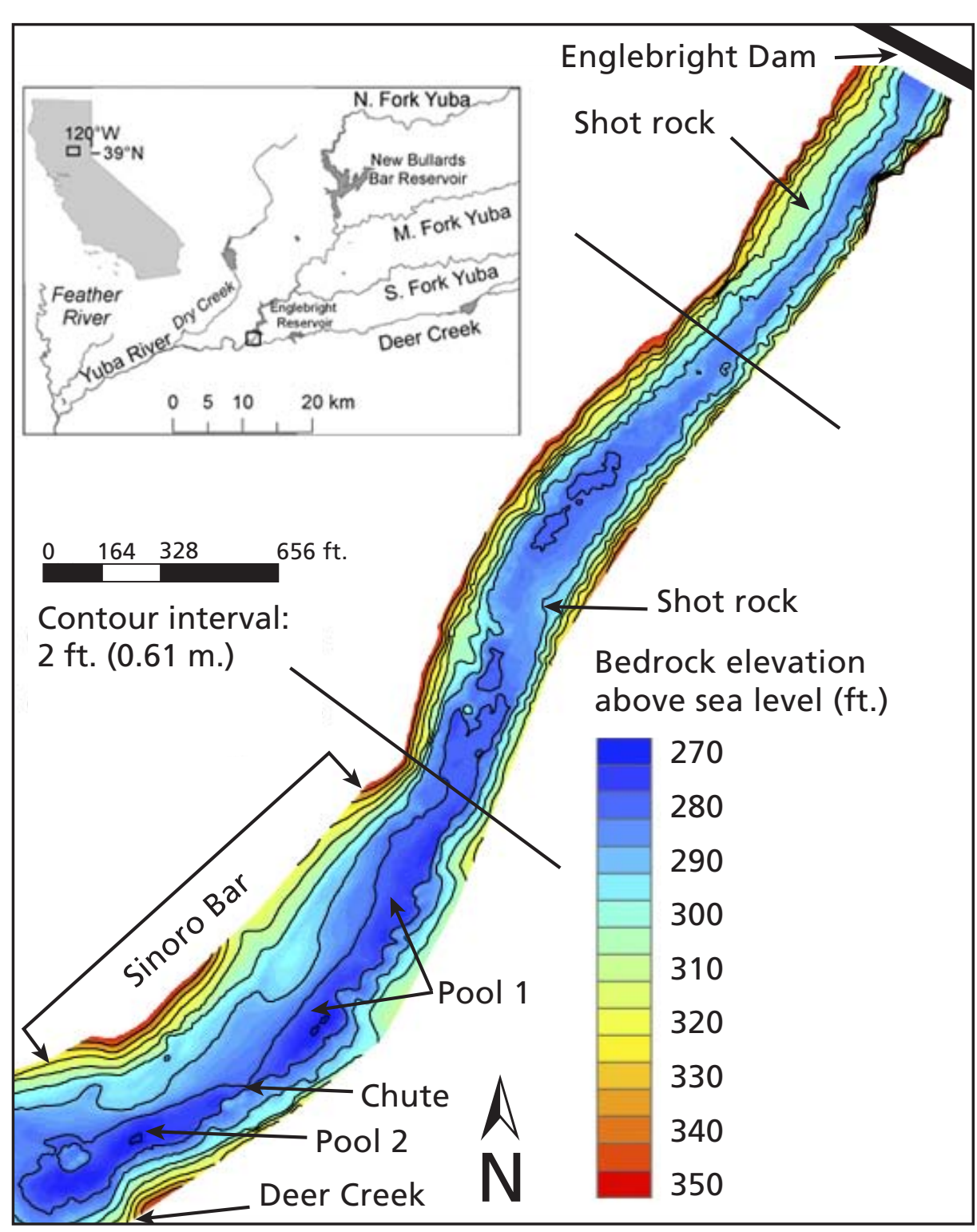

Fig. 1. Topographic map of the Englebright Dam Reach with inset map showing the canyon in the Yuba River basin. Total station-survey horizontal and vertical errors were typically within 0.2 to 0.8 inches ( 0.5 to 2 centimeters). RTK-GPS precisions was in the same range. A topographic digital elevation model (DEM) was produced using Geostatistical Analyst in ArcGIS 9.2. The build was performed via the radial basis function (tension with spline), yielding a mean vertical error of 1 centimeter and a vertical root mean square of 0.36 meter. the future as a dam-mitigation effort required by a National Marine Fisheries Service biological opinion (USACE 2007). The goal is for injected material to move downstream and form spring-run chinook salmon habitat in the canyon.

\section{River dynamics and salmon spawning}

The goal of our study was to characterize historical sedimentary and geomorphic changes in the vicinity of Sinoro Bar in the Englebright Dam Reach, because this area is a preferred spawning location for spring-run chinook salmon. Although the bar itself is 


\begin{tabular}{|c|c|}
\hline \multicolumn{2}{|c|}{$\begin{array}{l}\text { TABLE 1. Days in which peak discharge } \\
\text { was greater than } 1,840.6 \mathrm{~m}^{3} / \mathrm{s}(65,000 \mathrm{cfs}) \text { at } \\
\text { Smartville gage, Yuba River }\end{array}$} \\
\hline Date & Discharge \\
\hline & $\mathrm{m}^{3} / \mathrm{s}$ \\
\hline March 19, 1907 & $2,831.7$ \\
\hline Jan. 15, 1909 & $3,143.2$ \\
\hline March 26, 1928 & $3,398.0$ \\
\hline Dec. 11, 1937 & $2,101.1$ \\
\hline Jan. 21, 1943 & $2,296.5$ \\
\hline Nov. 21, 1950 & $3,086.5$ \\
\hline Dec. 23, 1955 & $4,190.9$ \\
\hline Feb. 8, 1960 & $2,435.2$ \\
\hline Feb. 1, 1963 & $4,247.5$ \\
\hline Dec. 22, 1964 & $4,842.2$ \\
\hline Jan. 21, 1970 & $2,664.6$ \\
\hline Feb. 19, 1986 & $2,831.7$ \\
\hline Jan. 2, 1997 & $4,360.8$ \\
\hline Dec. 31, 2005 & $2,707.1$ \\
\hline
\end{tabular}

alluvial, understanding its persistence and transformation within the bedrock canyon over known history would aid habitat rehabilitation for spring-run chinook salmon. We developed a conceptual understanding of dynamics in the Englebright Dam Reach by integrating a quantitative topographic analysis with an interpretive evaluation of historical channel conditions based on photographs.

Topographic analysis. To produce a detailed topographic map, three data sets were combined: (1) 9,283 ground elevation points on the surrounding hills digitized from 2-foot (0.67-meter) contour lines mapped in 1999 by the Army Corps of Engineers, (2) a terrestrial land survey inside the Englebright Dam Reach canyon using real-time kinematic global positioning system (RTK-GPS) and Robotic Total Station technology and (3) a boat-based fathometer survey of the submerged riverbed (Pasternack 2008).

We established local surveying benchmarks on the ground to form a rigorous control network, which tied together the boat and terrestrial surveys. The ground- and boat-based surveys obtained 55,739 points in the typical autumn low-flow, wetted channel. The mean point density of the data set calculated using Spatial Analyst in ArcGIS 9.2 (Environmental System Research Institute [ESRI], Redlands, CA) was one point every 1.6-by-1.6 square meters, with substantially higher density in the channel and lower density on the hillside.

Alluvial fill and bedrock. Spring-run chinook salmon require rounded gravel and cobble submerged under moder- ately fast water to spawn. Shot rock is not suitable for spawning, because its angular edges are sharp enough to mortally wound females as they repeatedly pound it to create a depression to lay their eggs, and then pound again to cover over eggs. Consequently, the shot rock in the Englebright Dam Reach needs to be removed as one phase in rehabilitating habitat. The first step in planning the removal is to evaluate the volume of alluvial fill. After removal, a similar volume of sediment — but high-quality, rounded river gravel and cobble - would need to be installed in the river to form riffles and bars with a more suitable geometry than that of Sinoro Bar. To estimate the spatial pattern of fill depth and total volume of sediment stored in Sinoro Bar, digital elevation model (DEM) differencing was performed in ArcGIS 9.2. DEM differencing involves subtracting an historic topographic map or a map of the estimated underlying bedrock surface from the modern topographic map to get either a channel-change map or an alluvial-fill volume, respectively. In this study the goal was to estimate total alluvial-fill volume to constrain the scope of shot rock removal cost at Sinoro Bar.

The challenge with this analysis was that the depth to bedrock under Sinoro Bar is unknown. The sediment on the bar is too coarse for seismic surveys, but ground-penetrating radar might work - though that method is also highly interpretive and uncertain. Ideally, excavation pits would be used alone or with ground-penetrating radar to determine shot-rock thickness, underlying alluvial thickness and the elevation of bedrock. Unfortunately, no funds were available for such a sophisticated assessment.

As a useful first estimate to guide further investigation, the elevation of the underlying bedrock relative to the North American Vertical Datum of 1988 was assumed to be a horizontal plane with an elevation based on that of the lowest elevation in the deepest pool adjacent to the bar, 269.30 feet (82.083 meters). This deep pool appears to have been artificially excavated, so it is the best estimate of the full thickness of the alluvial fill. Other sections in the reach show a horizontal bedrock bench with a very rough (i.e., not smooth) surface across the entire width of the river, so a U-shaped rather than a V-shaped cross section was thought to be the best assumption for a first estimate. Further, although the river does meander gently at this location, the bedrock itself may or may not be sloped from a high point on the hillside to a low point out in the channel. In fact, the next two bedrock meanders downstream do not show any side slope from the hillside into the channel. Instead, the hillside drops steeply to the riverbed. In this analysis, the spatial pattern of Sinoro Bar's topography at an elevation above 269.30 feet (82.083 meters) was determined, and was assumed to be all fill. The bar is too short for adjustment for lengthwise river slope in the plane to be worthwhile. In some areas bedrock may be deeper or shallower, yielding uncertainty.

There is no way to know if this value is an over- or underestimate. If an underlying bedrock platform or gentle side slope exists on the north bank, then this analysis overestimates fill volume locally along that flank. If the alluvial fill is deeper than the deepest pool depth, then this analysis underestimates fill volume overall. Fill depths per square yard were summed to obtain total fill volume. Perhaps the uncertainty in this estimate will motivate a future excavation to obtain a more accurate number.

Photographic analysis. UC Berkeley professor G.K. Gilbert took groundbased photos in 1909. For comparison, modern photos of the river were taken in 2008 from similar vantage points. Several other historical photos taken by a local landowner from 1960 to 2008

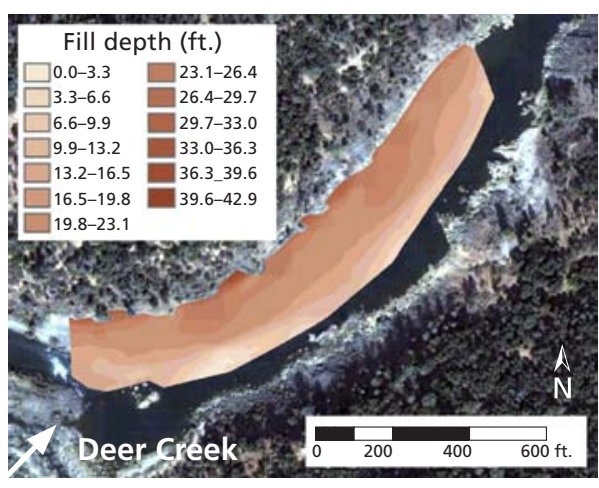

Fig. 2. Estimated sediment fill-depth map of Sinoro Bar, relative to a horizontal bedrock surface at $\mathbf{2 6 9 . 3}$ feet above sea level. 


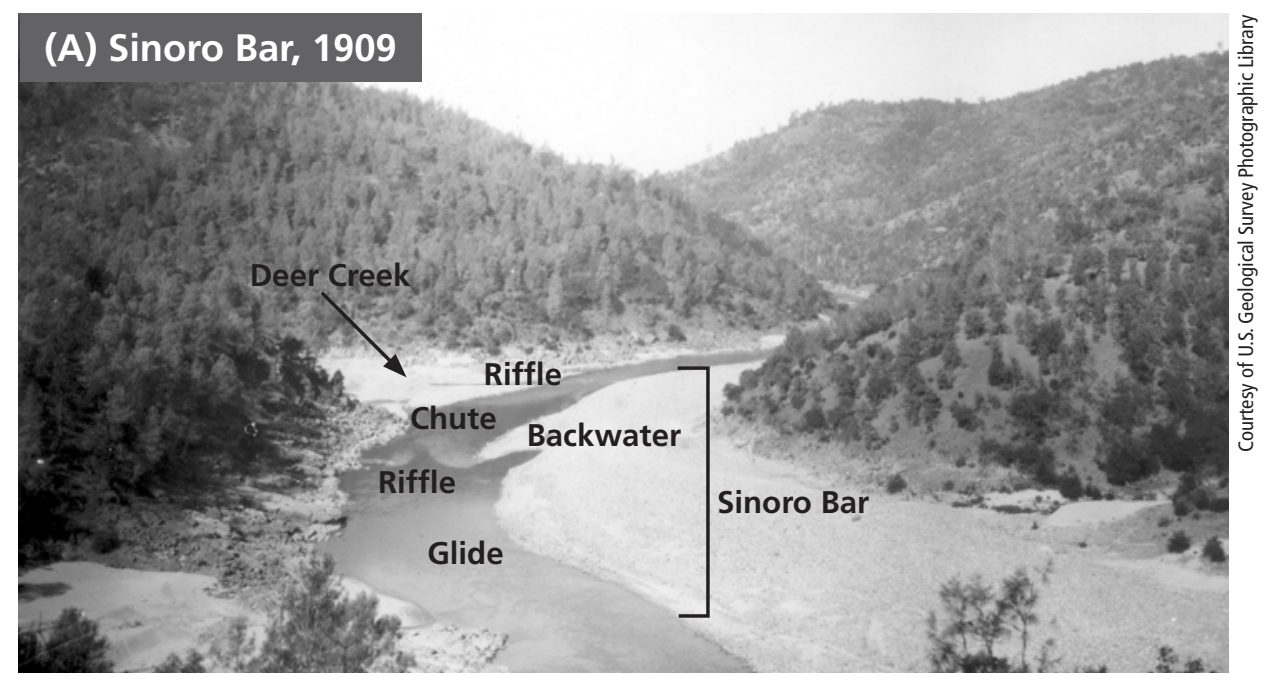

were inspected as well. In addition, nine aerial photos of the Englebright Dam Reach - georeferenced into the California State Plane Zone II horizontal coordinate system - were taken by various local, state and federal agencies at irregular intervals between 1937 and 2006. All photos were taken during base-flow conditions of less than 3,000 cubic feet per second (cfs) (85 cubic meters per second $\left.\left[\mathrm{m}^{3} / \mathrm{s}\right]\right)$, so they are comparable. The dates and mean daily discharges of peak flows during the largest historical floods were recorded by the Smartville gage (table 1).

Photo interpretation was used to determine what land forms and physical habitat conditions were present historically, focusing on Sinoro Bar and its vicinity. Substrate size classes (e.g., boulder, cobble/gravel, sand/mud), grains that are freshly turned over by flow, and the presence or absence of vegetation were visually evident in the photos. Aquatic physical habitat was defined as the assemblage of substrate, cover, water depth and water velocity. When interpreted at the scale of one channel width, the assemblage of features is termed "mesohabitat." A mesohabitat classification for the lower Yuba River, developed by Pasternack (2008), was used to describe elements in the photos.

The key units relevant to this study were emergent alluvial point bars and (in decreasing order of water depth) forced pool, pool, chute, recirculation, run, riffle entrance, glide, backwater and riffle (see glossary, page 70 ). There is a strong association between mesohabitat and spawning preference on the lower Yuba River, with chinook salmon preferring riffles the most, followed by riffle entrances, runs and secondary channels (Pasternack 2008). Interpreting changes to mesohabitats is predictive of changes in chinook utilization of the riverbed.

\section{Topography of the reach}

The Englebright Dam Reach is divided into three sections on the basis of canyon and channel widths (fig. 1). Half of the canyon width in the first 660 feet (200 meters) downstream of Englebright Dam is filled in with shot rock, so the channel is narrow and incised to bedrock. Then both the canyon and wetted channel widen, and the second shot-rock site

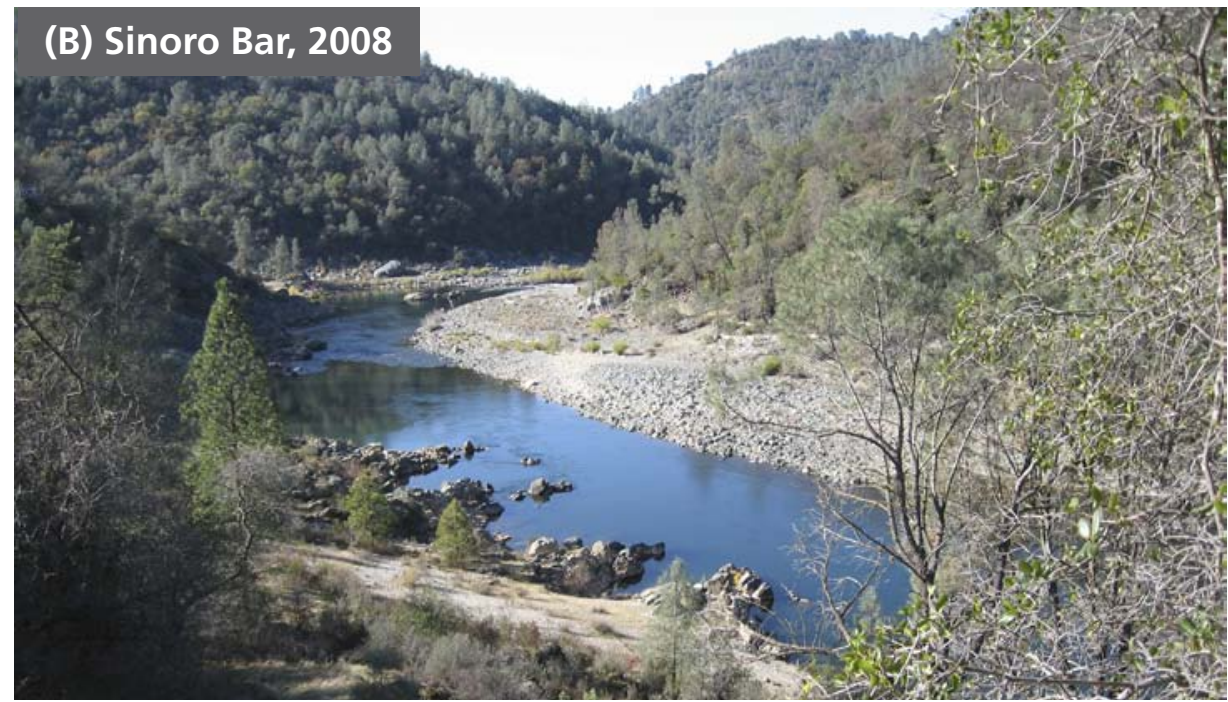

Fig. 3. (A) The 1909 image shows a sequence of mesohabitats. The upper riffle is located at the bedrock high point near the apex of the point bar, and the other riffle is adjacent to the mouth of Deer Creek. The bedrock high point does not appear to resemble any feature typical of alluvial meanders with tributary junctions, and instead appears to be related to the characteristics of the bedrock. The 1909 photo shows relatively little lateral and longitudinal elevation change in the channel - the entire area looks relatively flat. (B) The structure of physical habitat is different in 2008, with the upper riffle degraded to a chute composed of exposed bedrock and boulders with almost no gravel. The water looks slower and deeper upstream of the upper riffle. The surface of the point bar is still relatively flat, but the crosschannel relief is much greater, suggesting that the bar is less connected with the channel than in the past and that incision (a drop in elevation) of the riverbed due to erosion has occurred. Also, some vegetation is established on the point bar.

is located at a bump in the bed that constricts flow two-thirds of the way downstream. Finally, canyon width increases abruptly in the third section, and Sinoro Bar is located in the widest area. The two deepest pools in the reach, other than a scour hole at the base of the dam, are both adjacent to Sinoro Bar. One is upstream and one is downstream of the constricted chute opposite the apex of Sinoro bar (fig. 1). A bedrock high point explains why the chute is not as deep as the alluvial pools upstream and downstream of it.

DEM differencing yielded an esti- mated total alluvial volume of 168,650 cubic yards (128,940 cubic meters) for Sinoro Bar. Fill depth ranged from 0 to 39.7 feet (12.1 meters). Fill-depth contour lines were roughly parallel to the bank, decreasing toward the deepest part of the channel (fig. 2). Although the assumption of a horizontal bedrock surface underlying the bar at an elevation of 269.30 feet ( 82.083 meters) is uncertain, the resulting estimate of fill provides a useful constraint on the scope of shot rock removal and replacement with a similar volume of rounded river gravel/cobble. 

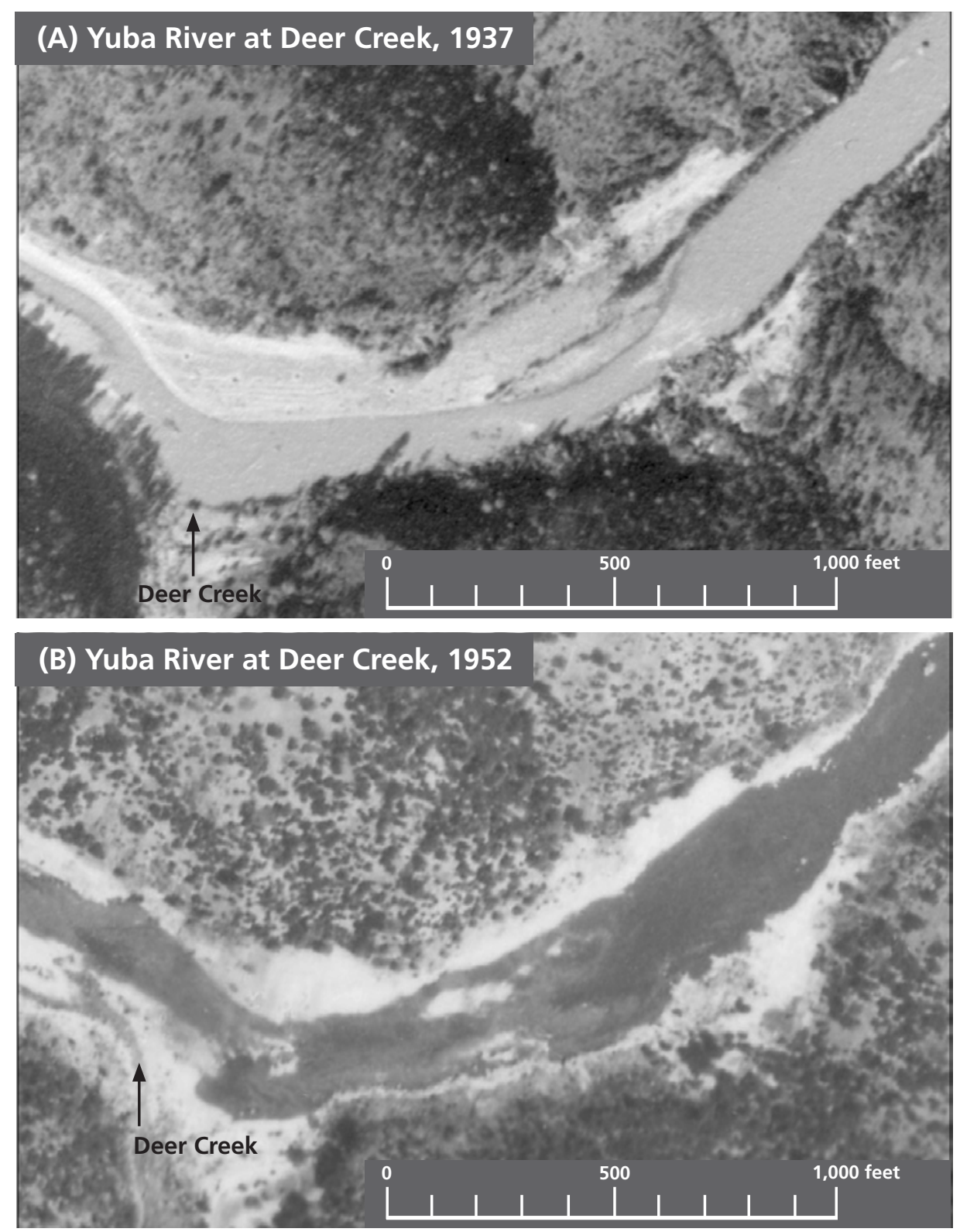

Fig. 4. (A) Since this photo predates Englebright Dam, the water could be turbid from the small peak of $692 \mathrm{cfs}\left(19.6 \mathrm{~m}^{3} / \mathrm{s}\right)$ on Oct. 15 (that event was still receding when the photo was taken) or simply a result of licensed hydraulic mining going on upstream at the time of photo acquisition. (B) By 1952, sediment has disappeared from the mouth of Deer Creek. Up until that time, the creek meandered through a substantial bar and terrace that was present on its river right (north bank). A large flood with an estimated peak discharge of 109,000 cfs $\left(3,086.5 \mathrm{~m}^{3} / \mathrm{s}\right)$ occurred between 1947 and 1952. It was the largest flood to have occurred since Englebright Dam was built, and could account for the loss of sediment.

\section{Images reveal history of change}

Earliest images. A direct comparison of the 1909 and 2008 ground-based photos of Sinoro Bar shows dramatic change (fig. 3). The Smartville gage discharge record shows that water rose on Jan. 2, 1909, peaked on Jan. 15 at about 111,000 cfs $\left(3,143.1 \mathrm{~m}^{3} / \mathrm{s}\right)$, and did not drop below 4,000 cfs $\left(113.3 \mathrm{~m}^{3} / \mathrm{s}\right)$ until June 27 . Gilbert's photo (fig. 3A) appears to have been taken after flows receded. It shows a large point bar on river right composed of well-rounded gravel, cobble and sand likely from hydraulic mining.
The bright surface of the bar and lack of shrubs suggest that the surface sediment was freshly deposited, consistent with 1909 being a flood year. Also, there is a large amount of hydraulic mining debris in the mouth of Deer Creek in the photo. In contrast, the 2008 photo (fig. 3B), coupled with direct visual observations, reveals angular boulders and cobbles overlying a mixture of sand, gravel and cobble. The downstream riffle is composed of boulders and cobble and it has steepened into a rapid with standing waves that indicate velocities too high for spawning salmon.

1937, 1947 and 1952. The first aerial photo is from autumn 1937, when flow was extremely low, just 140 cfs (3.96 $\mathrm{m}^{3} / \mathrm{s}$ ) (fig. 4A). It shows hydraulic mining sediments on the entire point bar as well as in the mouth of Deer Creek. The two riffles that were visible in the 1909 oblique photo are also evident. Despite the low flow, the water in the photo has the characteristic brightness and lack of contrast known to indicate high turbidity.

Overall, it appears that the same conditions present in 1909 persisted to 1937, because the dam was not yet built, and a large amount and a wide mix of sedimentary material was coming down from hydraulic mining sources. Given that the discharge was very low and the channel was visibly very wide compared to its present condition, it can be inferred that the water was shallow. Dark splotches on Sinoro Bar are indicative of vegetation establishment.

Despite being blurry and of low resolution, a 1947 photo (not shown) depicts hydraulic mining debris on both sides of the river. The water still looks turbid even though the dam was in place. The wetted channel is wider throughout the photo, consistent with the higher discharge at the time $(1,500 \mathrm{cfs}[42.48$ $\left.\left.\mathrm{m}^{3} / \mathrm{s}\right]\right)$. The photo also shows a large new deposit of sediment at the mouth and just downstream of Deer Creek. One of two sizable floods between 1937 and 1947 must have been responsible for this deposit.

The 1952 aerial photo (fig. 4B) is the first to show darkly colored, clear water. The discharge was the highest among all photos examined $\left(2,860 \mathrm{cfs}\left[80.99 \mathrm{~m}^{3} / \mathrm{s}\right]\right)$, but was only about $25 \%$ of modern $\mathrm{Q}_{\mathrm{b}}$. The wetted channel was a lot wider, and a noticeable amount of mining debris was gone. Also, three riffles were present instead of two. Based on the uniformity of pixel brightness, these riffles look like they still consisted of cobble, gravel and sand. Some of the material in the mouth of Deer Creek was gone, possibly due to a large flood event.

1952 to 1986 . There is a large gap in the aerial photo record from 1952 to 1986. Although photos were taken in 1957 and 1984, images of Sinoro Bar are lacking. However, ground-based photos 
provide some information. For example, a photo taken by a local landowner in 1960 shows a gold-mining operation in which coarse river sediment and shot rock were pushed out into the flow to expose underlying finer sediment (fig. 5). A turbidity plume downstream of the bulldozer demonstrates that mud existed in Sinoro Bar. The height of the bulldozer relative to the bar surface provides a vertical scale indicating that Sinoro Bar was high and its surface was already armored with shot rock in 1960. According to the oral history obtained from a local landowner, mining from 1937 to 1960 was limited to hand-based activity until a bulldozer arrived at the end of that period. Ground-based photos from 1971 also show large shot-rock boulders on Sinoro Bar.

Significant change took place between 1952 and 1986 (fig. 4B and fig. 6A). In aerial photos, the number of riffles decreased from three to two, and the original upstream riffle dating back to 1909 disappeared. The second historic riffle was the primary one at the site in 1986, but it appeared constricted due to the bulldozer pushing the bar further into the channel. Standing waves and white water indicate high velocities unsuitable for salmon spawning. The glide-riffle transition was abrupt in 1986, providing less spawning habitat than is evident in prior photos. The riffle at the end of Sinoro Bar was still wide and gravel-dominated in 1986, with little visual evidence of boulders or large cobble. In terms of the bar itself, a lot of mining sediment and increased vegetation were present on the downstream half of the bar. However, the upstream third of the bar was reduced in size and all material in the mouth of Deer Creek was gone.

Both of those locations appear to have been affected by mining. A mining pit was present on the upstream side of Sinoro Bar, as evidenced by the square shape of the wetted area in the hole and its unnatural position away from any scouring forces of river flow. In the mouth of Deer Creek a road was present. Four large floods occurred in the long period between photos, including two of the three largest on record, and one just 8 months before the 1986 photo was taken (table 1). Given both natural floods and extensive mining activity,

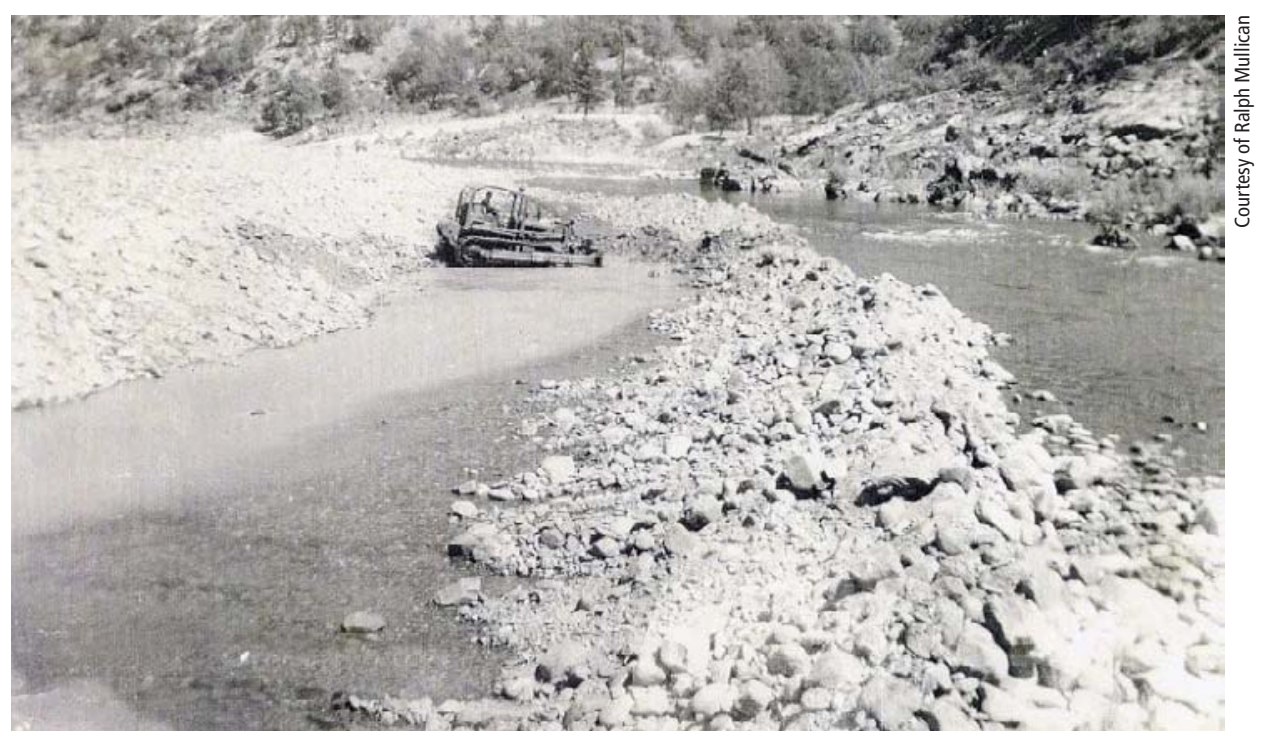

Fig. 5. A gold mining operation with a bulldozer at Sinoro Bar circa 1960.

it is difficult to say which caused more change, but the net effect is that Sinoro Bar and the mouth of Deer Creek lost a considerable amount of sediment, and overall, preferred spring-run chinook salmon habitat decreased substantially.

1986 to $\mathbf{1 9 9 6}$. The period from 1986 to 1996 was characterized by very low flows on the river, except for moderate peaks in May 1995 and May 1996. A summer 1996 aerial photo (not shown) depicts similar conditions for the upstream half of Sinoro Bar and the adjacent channel to those evident in 1986. The same two riffles are present, but the downstream one is narrower. Also, Sinoro Bar sediment still looks like a mix of cobble, gravel and sand. Vegetation still appears to be widespread on Sinoro Bar. The main change during this 10-year period was that the downstream half of the bar was visibly affected by mining, with a new hole and several vehicle tracks visible.

Ground-based photos confirm that extensive mining occurred in the mouth of Deer Creek and on the bar just downstream during this period. Mining included searches for gold in the historic hydraulic-mining sediments underlying the shot rock, and a bedrock and boulder harvesting operation for "Yuba Blue," a blue-green basalt rock of value in landscaping.

1997 to present. A rain-on-snow flood occurred Dec. 27, 1996, through Jan. 14, 1997, with the peak discharge occurring on Jan. 2 (table 1). That peak has the second-highest estimated flow in the entire historical record. There are no photos immediately following, but there is a ground-based photo from July 2,2001 , and a high-quality aerial photo taken in 2002 (fig. 6B). The 2002 aerial shows fresh deposits of sediments of a wide range of sizes, including shot rock. Mining pits on the bar were partially filled in. Image pixels of new debris show strong brightness contrast, indicative of coarse size and angular shape. Former pits are presently filled with 20 to 26 feet (6 to 8 meters) of fill due to the 1997 flood. Shot rock buried most of the vegetation evident in earlier photos. In terms of mesohabitats, the primary riffle present in 1986 was degraded to a chute by 2002. Also, the riffle at the end of the bar became heavily armored, with larger standing waves and more white water. It probably received a lot of coarse boulders and cobble that replaced preexisting finer gravels.

Photos from 2004, 2005 and 2006 (not shown) do not indicate much change from 2002. A large flood occurred Dec. 26, 2005, through Jan. 7, 2006, which caused the deposition of more shot rock on Sinoro Bar where mining pits used to be. There is no indication that 1997 shot rock was removed by the 2006 flood, suggesting that this is a highly stable deposition site.

\section{Factors affecting habitat}

The Englebright Dam Reach of the lower Yuba River is a bedrock canyon that contains remnant alluvial fill. No imagery of this reach predates hydraulic mining, but the history of gold mining at Landers Bar confirms that alluvium existed in the canyon. Hydraulic mining debris formed deep 

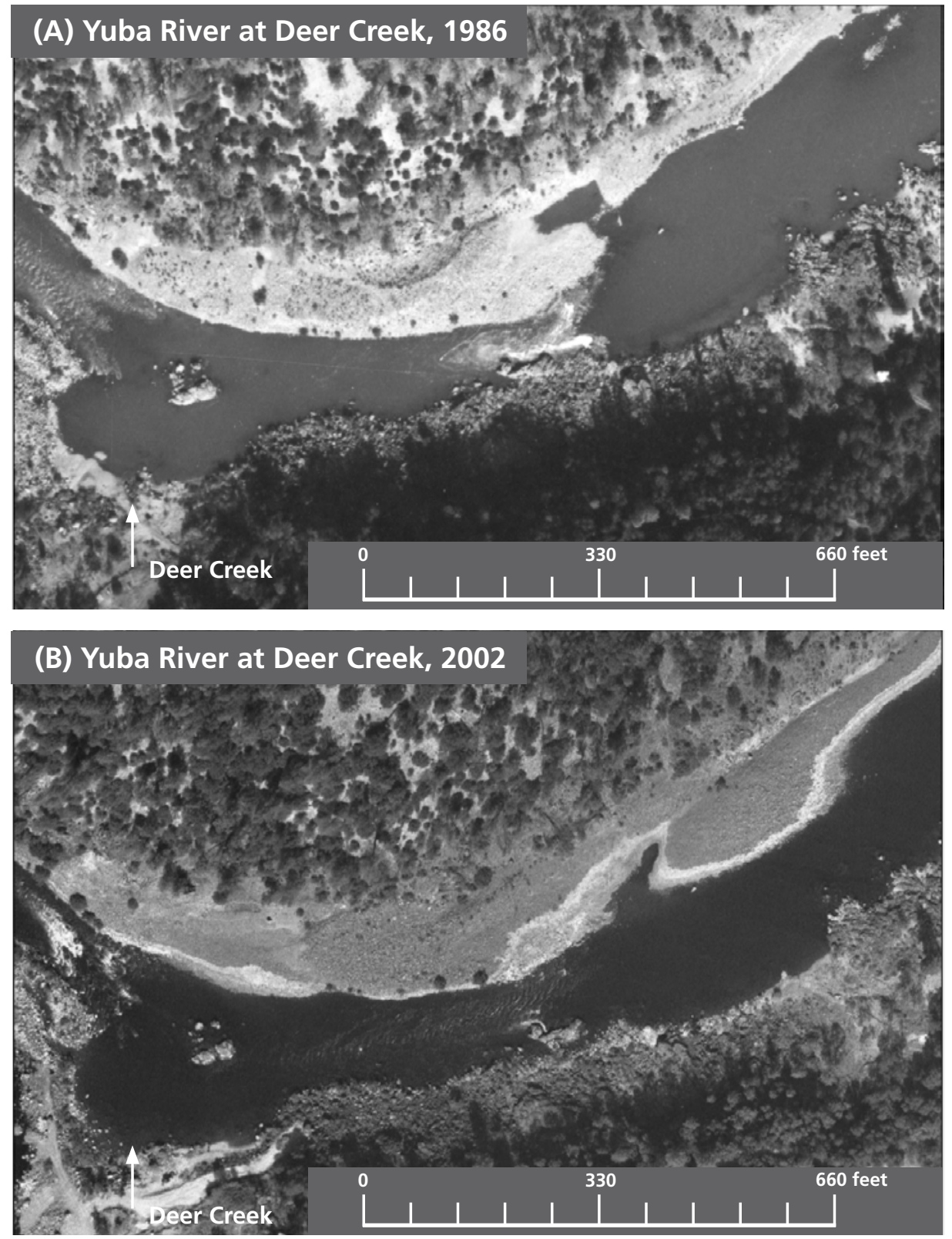

Fig. 6. Aerial photos of Sinoro Bar.

alluvial deposits in the reach, including multiple gravel-bedded riffles. Based on the size and shape of the riffles evident in the imagery, they would have provided spawning habitat for spring-run chinook salmon. As a reference for the scale of historic gravel input to the Englebright Dam Reach, a sediment-budget analysis found that on average about 77,520 metric tons per year of gravel and cobble (not counting sand and mud) deposited in Englebright Lake from 1942 to 2004 (Pasternack 2008; Snyder et al. 2004). A supply of at least that magnitude was responsible for forming Sinoro Bar in the first place, but it was so large that it filled in the entire river corridor from Narrows Pool down to Marysville.

After Englebright Dam was built, a large quantity of highly angular shot rock was introduced to the canyon and allowed to migrate downstream in floods, even as the upstream supply of gravel was cut off. The burial and replacement of gravel bars by shot rock since 1942 has degraded salmon spawning habitat. More historic shot rock and recently excavated cobblesized angular rock are present below Englebright Dam and could cause future degradations, depending on how well the bars are protected from erosion during large floods.
Gold mining on Sinoro Bar became mechanized around 1960 and was responsible for degrading salmon habitat. Prior to mining with bulldozers, glideriffle transitions were gradual, enabling fish to select among a diverse range of local hydraulic conditions. Bulldozer debris constricted the channel significantly, induced abrupt hydraulic transitioning and caused the main riffle at the apex of the bar to degrade into a chute unsuitable for spawning. In addition, mining operations evacuated the majority of alluvium at the mouth of Deer Creek, destroying what was likely a hotspot for biological productivity and salmon spawning. Shot rock has not filled in the hole in the outer bed of the river but has filled in mining holes on Sinoro Bar, consistent with well-known channel-bed hydrodynamics and sediment transport patterns. Overall, the impact of mechanized in-stream gold mining was significantly greater than the impact of Englebright Dam on changing the geometry and structure of Sinoro Bar.

The Englebright Dam Reach locations where shot rock deposited in the past may be viewed as a natural sediment transport "experiment" revealing the fate of coarse sediment introduced on the hillside adjacent to Englebright Dam. Large floods pick up alluvium in the highly constricted top 660 feet (200 meters) of the reach and primarily deposit them in the widest section of the canyon, which also happens to occur in the backwater zone associated with Deer Creek floods. Sinoro Bar is located in this zone. Thus, Englebright Dam has affected the Englebright Dam Reach by causing angular boulders and cobbles to be torn off the hillside and lifted off bedrock terraces to end up on Sinoro Bar. Based on the historical deposition pattern of hydraulic mining sediment and shot rock, gravels injected at Englebright Dam and mobilized by future floods are most likely to deposit at Sinoro Bar. Even though shot rock takes up space where gravel might go, there is still room in the wide section of Englebright Dam Reach for gravel to deposit. 


\section{Rehabilitating Sinoro Bar}

Large floods do not appear to scour Sinoro Bar, but rather to add more shot rock to it. Thus, rehabilitation of salmon spawning habitat requires shot-rock removal. Merely exhuming gravel-rich hydraulic mining debris will not yield salmon habitat in and of itself, because historic mining operations reconfigured the bar to an unsuitable geometry. Furthermore, there is little gravel at the mouth of Deer Creek due to local mining and an upstream dam that should be addressed. These findings suggest that shot-rock removal should only be undertaken if it is combined with largescale gravel placement and spawning habitat rehabilitation (Wheaton et al. 2004a, 2004b). The scale of initial gravel placement ought to be about 130,000 cubic yards (100,000 cubic meters) roughly two-thirds the volume of Sinoro bar itself. It would also be sensible to investigate methods for preventing future spills over the dam from tearing rock off the hillside.

Suitable rounded river gravel is available from a quarry near the Highway 20 bridge as well as numerous tailing berms downstream. These materials can be sorted and thoroughly washed to remove mercury-bearing clay and fine silt prior to reintroduction to the channel. Even if some mercury is reintroduced, the water, riverbed and hyporheic zone are well oxygenated in the river between Englebright Dam and the Highway 20 bridge, so there is little risk of forming hazardous methylmercury in that segment. Downstream of the Highway 20 bridge, there are ample sources of mercury in terraces composed of hydraulic mining sediment (James et al. 2009) and likely in the alluvial fill underlying the riverbed, which is composed of the same source material. Exposure and reworking of one small bar of historical sediment would likely have a negligible effect on possible mercury contamination, relative to the existing large inventory of mercury available downstream.

Once the site is rehabilitated, gravel injection at Englebright Dam could sustain it. Existing shot rock and friable hillsides at the dam should be further stabilized to reduce erosion. Then a gravel injection program should be established to feed gravel to the Sinoro Bar area. This has the benefit of possibly yielding smaller pockets of deposition further up in the canyon behind local obstructions (Fulton 2008) and avoids impacts on local landowners adjacent to Sinoro Bar. Based on our experience with gravel injection in California, about 13,000 cubic yards (10,000 cubic meters) per year (in conjunction with rehabilitation of the Sinoro Bar site) would promote sustainable deposition behind flow obstructions and would be large enough to support a spring-run chinook salmon population of about 4,000 fish as well as replenish any losses to mesohabitat in the Sinoro Bar area.

If no large-scale gravel placement is done at Sinoro Bar at the time of shotrock removal, then injection of about 26,000 cubic yards (20,000 cubic meters) per year at the dam would likely be large enough to yield sustainable gravel bar and riffle formation down at Sinoro Bar in 5 to 15 years, depending on the flood regime. After that, the injected amount could be reduced to a maintenance level of about 13,000 cubic yards (10,000 cubic meters) per year. However, direct gravel placement would have the benefit of providing immediate spring-run chinook salmon habitat for all freshwater life stages with much less uncertainty.

G. Pasternack is Professor of Watershed Hydrology, Department of Land, Air, and Water Resources, UC Davis; A.A. Fulton is Consultant, Questa Engineering Corporation, Richmond, CA; and S.L. Morford is Ph.D. Student, Soils and Biogeochemistry Graduate Group, UC Davis.

The U.S. Fish and Wildlife Service Anadromous Fish Restoration Program provided financial support for this work (Agreement \#113323J011). The authors gratefully acknowledge Jason White and Jimmy Kulpa for their assistance in the collection of topographic field data. Aerial photos were obtained from Professor Allan James (University of South Carolina), the UC Davis Shields Library, DigitalGlobe Inc. (Longmont, CO), Jones and Stokes (Sacramento, CA), Globe Xplorer NAIP and Airphoto USA Archives. Anonymous reviewers provided useful edits to the manuscript.

\section{References}

Banks MA, Rashbrook VK, Calavetta MJ, et al. 2000. Analysis of microsatellite DNA resolves genetic structure and diversity of chinook salmon (Oncorhynchus tshawytscha) in California's Central Valley. Can J Fish Aquat Sci 57:915-27.

Curtis JA, Flint LE, Alpers CN, Yarnell SM. 2005 Conceptual model of sediment processes in the upper Yuba River watershed, Sierra Nevada, CA Geomorphology 68:149-66.

Fulton AA. 2008. Gravel for Salmon in Bedrock Channels: Elucidating Mitigation Efficacy Through Site Characterization, 2D-Modeling, and Comparison along the Yuba River, CA. Master's thesis, Department of Hydrologic Science, UC Davis, CA $110 \mathrm{p}$.

James LA. 2005. Sediment from hydraulic mining detained by Englebright and small dams in the Yuba basin. Geomorphology 71:202-26.

James LA, Singer MB, Ghoshal S, Megison M 2009. Sedimentation in the lower Yuba and Feather rivers, California: Long-term effects of contrasting river management strategies. In: James LA, Rathburn SL, Whittecar GR (eds.). Management and Restoration of Fluvial Systems with Broad Historical Changes and Human Impacts. Geological Society of America, Boulder, CO. p 57-82.

McReynolds TR, Garman CE. 2008. Butte Creek spring-run Chinook salmon, Oncoryhnchus tshawytscha, pre-spawn mortality evaluation, 2007. California Department of Fish and Game, Ranco Cordova, CA. Inland Fisheries Report No. 2008-2.

Pasternack GB. 2008. SHIRA-based river analysis and field-based manipulative sediment transport experiments to balance habitat and geomorphic goals on the lower Yuba River. Cooperative Ecosystems Studies Unit (CESU) 813326 J002, Final Report. UC Davis, CA.

Snyder NP, Rubin DM, Alpers CN, et al. 2004. Estimating accumulation rates and physical properties behind a dam: Englebright Lake, Yuba River, Northern California. Water Resources Research 40(W11301):1-19. doi: 10.1029/2004WR003279.

[USACE] US Army Corps of Engineers. 2007. Lower Yuba River pilot gravel injection project, Yuba and Nevada counties, California - draft environmental assessment. Sacramento District, CA. p 59.

Wheaton JM, Pasternack GB, Merz JE. 2004a. Spawning habitat rehabilitation-I. Conceptual approach and models. Int J River Basin Manage 2(1):3-20.

Wheaton JM, Pasternack GB, Merz JE. 2004b. Spawning habitat rehabilitation-II. Using hypothesis development and testing in design, Mokelumne River, California, USA. Int J River Basin Manage 2(1):21-37.

Wohl E, Tinkler KJ. 1998. A primer on bedrock channels. In: Wohl E, Tinkler KJ (eds.). Rivers Over Rock: Fluvial Processes in Bedrock Channels. American Geophysical Union, Washington, DC.

Yoshiyama RM, Gerstung ER, Fisher FW, Moyle PB. 1996. Historical and present distribution of chinook salmon in the Central Valley drainage of California. UC Centers for Water and Wildland Resources,

Davis. In: Brown RL (ed.). Contributions to the Biology of Central Valley Salmonids. Vol. 1. California Department of Fish and Game, Fish Bulletin 179, p 71-176. 